УДК 336.71

DOI: https://doi.org/10.37320/2415-3583/21.12

Чупріна М.O.

кандидат економічних наук, доцент Національний технічний університет Украӥни «Київький політехнічний інститут імені Ігоря Сікорського» ORCID: https://orcid.org/0000-0002-3276-4473

Лазоренко Т.В.

кандидат економічних наук, доцент Наиіональний технічний університет Украӥни «Київський політехнічний інститут імені Ігоря Сікорського» ORCID: https://orcid.org/0000-0001-7895-1306

\title{
УПРОВАДЖЕННЯ ІННОВАЦІЙНИХ ТЕХНОЛОГІЙ КРЕДИТУВАННЯ В УМОВАХ ЕЛЕКТРОННОЇ КОМЕРЦЇ̈
}

\begin{abstract}
У статті визначено, шо саме розвиток електронних систем створює нову віртуальну реальність для ведення иілком реального бізнесу у сфері електронної комериіі. Зазначено, щзо впровадження інноваційних технологій кредитування у сферу Інтернет-комериії зумовлено тим, щьо на даному етапі розвитку як української, так і світової банківської системи все більше банків збільшують пакет Інтернет-послуг. Доведено, щзо впровадження інноваційних технологій кредитування надає можливості значно скоротити час обробки інформації, дистаниійного обслуговування клієнтів $i$, як наслідок, нарощування клієнтської бази. Проведено аналіз світових обсягів та визначено основні тренди розвитку електронної комериії з урахуванням умов світової пандемії COVID-19, а саме: загальна глобалізація та розмиття кордонів; використання інноваційних інформаџійних технологій VR/AR; голосове керування; штучний інтелект; використання мобільних пристроїв у сфері комериії. Деталізовано нові тенденції та основні проблеми та підкреслено, щзо вітчизняний ринок електронної комерції дотримується загальних світових трендів зі специфічними векторами розвитку. Розглянуто приклади застосування в Украӥні інноваційних банківських ичифрових інновацій, особливу увагу приділено основним крокам упровадження інновачійних технологій кредитними установами.
\end{abstract}

Ключові слова: електронна комериія, інформаційні технологї, інноваційні технологї̈ кредитування.

Постановка проблеми. У сучасному світі інформаційні технології займають важливе місце майже в усіх секторах економіки. Комп'ютеризація сфери торгівлі у цьому процесі відіграє надзвичайно важливу роль. Розвиток електронних систем створив нову віртуальну реальність для ведення цілком реального бізнесу у сфері електронної комерції. Повна автоматизація процесів вПлинула на швидкість, мобільність, зручність надання послуг і стала невід'ємною частиною життя сучасної людини в усьому світі. Упровадження інноваційних технологій кредитування у сферу Інтернеткомерції зумовлене тим, що на даному етапі розвитку як української, так і світової банківської системи все більше банків почали надавати розширений пакет Інтернет-послуг, які допомагають значно скоротити час обробки інформації, надають можливість дистанційного обслуговування клієнтів i, як наслідок, нарощування клієнтської бази.

Аналіз останніх досліджень і публікацій. Окремі аспекти визначення понять електронного бізнесу та впровадження інноваційного кредитування в умовах електронної комерції розглядаються у працях таких учених, як О. Мошенець, К. Новікова, А. Старатович, Є. Стрельчук, Т. Тардаскіна, В. Ткачук, О. Юдін [1-5] та ін. Віддаючи належне теоретичній та практичній цінності попередніх здобутків, залишається багато невирішених питань - від технологічного розвитку електронної комерції до моменту імплементації саме інноваційних технологій кредитування у цій сфері діяльності.
Мета статті полягає у визначенні основних світових трендів розвитку діяльності у сфері електронної комерції та дослідженні прикладних аспектів упровадження інноваційних технологій кредитування, зокрема в умовах світової пандемії COVID-19.

Виклад основного матеріалу. Розвиток сучасних методів ведення бізнесу, безумовно, дає потужний поштовх для його модернізації. Однією $з$ таких течій $є$ розвиток електронної комерції. У іiі контексті з'являється багато нових методів та підходів до оптимізації цього процесу. Сфера електронної торгівлі товарами та послугами (e-commerce) сьогодні займає значне місце у житті людей та в економіці країни у цілому.

Світові обсяги електронної комерції, за даними, що наведені у звіті статистичного порталу Statista, у 2020 р. вже перевищують \$2 трлн [6]. Частка онлайнпродажів у загальній структурі рітейлу постійно збільшується з 8,7\% у 2016 р. до 14,2\% у 2020 р. та, за прогнозами аналітиків, у 2021 р. досягне 15,5\%.

На світовій арені тенденції в електронній комерції формують Китай та США. Зазначимо, що почався зсув купівельної спроможності зі США та Європи в Китай та Південно-Східну Азію, цьому сприяє зростаюче число азіатських споживачів, які отримують доступ до електронної комерції завдяки зростанню купівельної спроможності та проникненню Інтернету, особливо на мобільних пристроях.

Європейський ринок рітейлу демонструє також тенденції до зростання. Так, у 2020 р. обсяг електронної торгівлі в Свропі становив Є717 млрд, що на 12,7\% 
більше порівняно з показниками 2019 р. [7]. Зазначимо також, що активніше здійснюють покупки в Інтернеті в таких країнах, як Великобританія, Данія та Німеччина.

Безумовно, аналіз діяльності у сфері електронної комерції потребує урахування умов світової пандемії COVID-19. Отже, підвищений попит став проблематичним не лише для продавців, а й для всієї логістики. У момент замкнутості та ізоляції люди сповільнилися і стали більше цінувати навколишній світ, що зробило питання екології ще більш важливим. Споживачі вимагають від продавців поставляти більш екологічно чисті продукти, особливо це $\epsilon$ характерною ознакою для електронної торгівлі в Європі. Отже, на думку авторів, у майбутньому електронній комерції доведеться зіткнутися 3 наслідками світової пандемії, 3 Brexit, який залишається невирішеним у багатьох аспектах (включаючи торгівлю), та переходом на більш екологічні товари.

Вітчизняний ринок електронної комерції характеризується також тенденцією до стрімкого зростання. За прогнозними оцінками аналітиків компанії Ukrainian E-commerce Expert, обсяг вітчизняного ринку електронної комерції в 2021 р. може досягти 6 млрд грн [8].

При цьому серед характерних ознак вітчизняного ринку електронної комерції слід виділити сильну цінову конкуренцію та автоматизацію бізнес-процесів. Із великим ступенем вірогідності можна прогнозувати, що в сучасних умовах світової пандемії електронна комерція в Україні може зайняти до 80-90\% частки класичної торгівлі та значною мірою вплине на зміну таких сфер діяльності, як логістика, ринок безготівкових платіжних систем та рекламний бізнес.

Проведений аналіз дає змогу також визначити основні світові тренди розвитку електронної комерції. По-перше, загальна глобалізація i розмивання кордонів. Наприклад, китайські майданчики (Alibaba, Aliexpress та ін.) проникають на ринок інших країн, тим самим створюючи конкуренцію локальним онлайнрітейлерам. Серед чинників, які забезпечують успіх китайського бізнесу, можна виділити прямий доступ до виробників величезної кількості товарів і кооперацію з логістичними компаніями, що забезпечує швидку доставку покупок практично по всьому світу.

Другий масштабний тренд - використання інноваційних інформаційних технологій: віртуальної і доповненої (VR/AR), голосового управління, штучного інтелекту та аналізу великих масивів інформації. Рітейлери намагаються аналізувати запити покупців, їхні поведінку та настрій, а також використовувати весь інструментарій із метою показати товар у найбільш привабливому вигляді. Наприклад, китайська компанія Tmall випускає спеціальні AR-ігри для продажу товарів і розробляє «віртуальні магазини», де покупець за допомогою спеціального обладнання може переміщати і вибирати товари [8].

Наступний світовий тренд розвитку електронної комерції безпосередньо пов'язаний із попереднім перехід на «мобайл», тобто використання мобільних пристроїв у всіх сферах електронної комерції. Дослідження аналітиків маркетплейсу Prom.ua дають змогу зробити висновок, що власники смартфонів більш схильні до імпульсивних покупок, аніж користувачі ПК. Більше того, мобільний онлайн-шопінг доступні- ший, тому що користувачі не прив'язані до комп'ютерів. Зазначимо, що саме маркетплейси - одна $з$ найперспективніших і швидко зростаючих ніш електронної комерції. Саме на їхній розвиток і роблять ставку провідні гравці ринку рітейлу. Цей тренд добре простежується і в Україні: саме з мобільних пристроїв (не враховуючи трафік із мобільних додатків) заходить понад $60 \%$ користувачів під час онлайн-шопінгу і саме цей сегмент росте мінімум удвічі швидше, ніж усі сфери електронної комерції [9]. Отже, вітчизняний ринок електронної комерції слідує основним світовим трендам із певними специфічними векторами розвитку, а саме:

- транскордонна торгівля - один із найбільш перспективних векторів розвитку українського Інтернетрітейлу;

- інтеграція офлайн- і онлайн-торгівлі;

- виділення окремого сегменту online-travel (онлайнпродаж авіа-, автобусних та залізничних квитків);

- розвиток бізнес-рішень із «неокласичної» електронної торгівлі (будматеріали, медичні послуги) та взаємодія з державою (моделі b2g i g2b).

За прогнозами фахівців EVO.company, в Україні намітилися певні тенденції зі зміни драйверів електронної комерції, а саме:

- перехід від покупок в Інтернеті електроніки, авіа- та залізничних квитків, побутової техніки, одягу, взуття та аксесуарів до «нетрадиційних» для електронної комерції товарів: продуктів харчування, алкоголю та медичної допомоги;

- зміцнення позицій маркетплейсів;

- позитивний вплив ринок Інтернет-рітейлу надає розвитку логістичних компаній («Нова Пошта», «Інтайм», «Justin», «Укрпошта» та ін.);

- розвиток безготівкових платежів [9].

Зазначимо, що впровадження інноваційних банківських цифрових новацій та початок карантинних заходів в Україні продемонстрували збільшення кількості трансакцій за картками та відхід від класичного використання пластикових карток. За даними Українського процесінгового центру (UPC), загальна кількість трансакцій за картками у 2020 р. порівняно з 2019 р. зросла на 11,0\%, а обсяги долали 7,2\% [10]. Аналізуючи використання інноваційних технологій в Україні, варто звернути увагу на систему безконтактних розрахунків від Mastercard PayPass, яка дає змогу здійснювати розрахунки в магазинах та метро. Також зазначимо, що компанія Google у партнерстві з Mastercard i АТ «КБ «ПриватБанк» запустила в Україні глобальний сервіс AndroidPay, який дає змогу здійснювати безконтактні розрахунки смартфонами. Інтернет-магазини, підключені до еCommerceConnect, зараз можуть приймати платежі за допомогою цифрових гаманців ApplePay и GooglePay.

Заслуговує також уваги спільна розробка міжнародної платіжної системи Visa i AT «КБ «ПриватБанк» iз застосування електронної технології Visa Token Service. Вона забезпечує безпечне середовище для розвитку інновацій у сфері електронної комерції.

Отже, як було зазначено вище, розвиток електронної комерції та світова пандемія зумовлюють міграцію покупців із реальних супермаркетів в Інтернет-магазини. За мінливим товарним трафіком слідують і кредитні установи - банки і небанківські фінансові компа- 
нії. Зараз практично кожен має партнерські банки або фінансові компанії. У цьому разі йдеться про кредити, що видаються безпосередньо в точках продажів на покупку товару. Сдина важлива відмінність - це фізична відсутність покупця (позичальника) в магазині. Інтернет як середовище здійснення покупок диктує свої вимоги до процесів. Для продавця додаткових ускладнень не виникає: клієнт бачив і хоче купити, товар доставляє кур'єр, і в цей момент можна все перевірити, підписати необхідні папери, передати чеки тощо. Але переважна більшість вітчизняних банків поки що не готова до нових викликів, тобто не готова підтвердити кредит без фізичної присутності позичальника (з паспортом та ідентифікаційним кодом), а потім передати договір на підписання разом із кур'єром, який здійснює поставку товару. 3 огляду на вищевикладені реалії, онлайн-продавці і банки готові надати своїм клієнтам лише компромісне, «гібридне» рішення у сфері онлайн-кредитування. Банки готові видавати кредити на покупку в Інтернеті на термін до трьох років. Схема, розроблена банками для Інтернет-магазинів, виглядає приблизно так:

- позичальник відправляє заявку на отримання кредиту для покупки товару на сайті продавця. Заявка надходить одному або декільком банкам-партнерам;

- банк телефонує позичальнику для проведення співбесіди;

- банк може запросити клієнта для надання оригіналів документів і підписання кредитного договору в найближче до позичальника відділення;

- банк може схвалити заявку і запропонувати клієнту підписати договір про кредитування 3 представником банку в точці видачі товару Інтернет-магазину;

- банк перераховує кошти Інтернет-магазину за вибраний клієнтом товар;

- товар передається покупцеві.

Особливе місце на ринку онлайн-кредитування займає розстрочка від АТ «КБ «ПриватБанк», який зараз має великий тиск на онлайн-кредиторів, просуваючи кредитні програми у рамках карткових продуктів. Так, АТ «КБ «ПриватБанк» пропонує три модифікації продукту. У будь-якому із цих варіантів необхідно бути власником картки банку. Сервіси доступні власникам карток «Універсальна», «Універсальна Gold» і елітних карток для VIP-клієнтів (Platinum, Infinite, World Signia/ Elite). Після вибору товару в Інтернет-магазині слід вибрати конкретний тип розстрочки, вказати кількість платежів і зробити покупку. 3 картки буде списано перший платіж, а товар буде доставлений кур'єром. Далі кожні 30 днів від моменту покупки з карти списуватиметься сума щомісячного платежу. Якщо на карті немає необхідної суми, оплата буде відбуватися в рахунок кредитних коштів зі стягненням комісійних у розмірі 4,0\% від суми. У разі дострокового погашення стягується 2,9\% від загальної суми договору. Отже, кредитні картки цілком можуть розглядатися як альтернатива кредитам на купівлю в Інтернет-магазинах.

Окрім того, зараз чимало фінансових компаній пропонують видачу онлайн-кредитів із зарахуванням кредитних коштів на наявну у позичальника банківську картку. Такий кредит можна отримати он-лайн, але недолік полягає у збільшенні вартості послуги та відносно невеликих сумах таких позик.

Незважаючи на всі недоліки технології онлайн-кредитування, можливість кредитування у разі онлайнпокупок цікава Інтернет-магазинам, оскільки для них така опція є складником просування товарів. А також надає додаткові можливості для збільшення обсягу продажів та розглядається як один 3 інструментів залучення нових клієнтів. Інтернет-магазини, в яких $є$ онлайн-кредитування, відзначають зростання середнього чека. На думку учасників ринку, затребувані онлайн-кредити, які Інтернет-роздріб пропонує від банку-партнера без необхідності відвідувати відділення цього банку. У цьому разі приріст продажів магазину може становити до 35,0\%. Зазначимо, що такі продукти виглядають найбільш конкурентоспроможними, оскільки позбавлені багатьох умовностей і застарілих вимог банківського кредитування.

Висновки. За результатами дослідження вирішено наукове завдання 3 розвитку наукових положень технологічного розвитку електронної комерції, а саме імплементації інноваційних технологій кредитування у цій сфері діяльності. Проведено аналіз світових обсягів та визначено основні тренди розвитку електронної комерції з урахуванням умов світової пандемії COVID-19. Проведений аналіз дав змогу зробити висновок, що вітчизняний ринок електронної комерції дотримується загальних світових трендів зі специфічними векторами розвитку. Практичне значення отриманих результатів полягає у визначенні напрямів використання інноваційних банківських цифрових інновацій, а саме: системи безконтактних розрахунків від Mastercard Pay Pass, упровадження глобального сервісу Android Рау та застосування електронної технологіï Visa Token Service. Особливу увагу приділено основним крокам упровадження інноваційних технологій кредитними установами. Зазначимо, що використання інноваційних технологій кредитними установами має широкий спектр переваг, тому подальші дослідження необхідно спрямувати на вдосконалення нормативноправової платформи взаємодії постачальника послуг та користувачів.

\section{Список використаних джерел:}

1. Мошенець О.В. Інноваційні продукти і технології на ринку банківських послуг. Фінансовий ринок Украӥни. 2011. № 12. C. 7-8.

2. Новикова К.В., Старатович А.С., Медведева Е.О. Интернет-маркетинг и электронная коммерция : учебно-методическое пособие. Пермь : Перм. гос. нац. исслед. ун-т, 2013. 78 с.

3. Тардаскіна Т.М., Стрельчук С.М., Терешко Ю.В. Електронна комерція : навчальний посібник. Одеса : ОНАЗ ім. О.С. Попова, 2011. 243 с.

4. Ткачук В.О. Інноваційна політика банків на ринку банківських послуг. Економічний аналіз. 2013. Т. 14. № 2. С. 43-51.

5. Юдін О.М., Макарова М.В., Лавренюк Р.М. Системи електронної комерції: створення, просунення і розвиток : монографія. Полтава : РВВ ПУЕТ, 2011. 201 с.

6. Звіт з електронної комерції статистичного порталу Statista за 2020 рік. Statista : вебсайт. URL: https://www.statista.com/ study/42335/ecommerce-report/ (дата звернення: 10.03.2021). 
7. Ecommerce in Europe: $€ 717$ billionin 2020. EcommerceNewseurope : web-site. URL: https://ecommercenews.eu/ecommercein-europe-e 717-billion-in-2020/\#: :text=Ecommerce\%20in\%20Europe \%20is\%20expected,the\%20European\%20ecommerce\%20 in\%202019 (дата звернення: 15.03.2021).

8. E-commerce. URL: https://e-ommerce.com.ua/category/\%d1\%8d\%d0\%bb\%d0\%b5\%d0\%ba\%d1\%82\%d1\%80\%d0\%be $\% \mathrm{~d} 0$ $\%$ bd $\% \mathrm{~d} 0 \% \mathrm{bd} \% \mathrm{~d} 0 \% \mathrm{~b} 0 \% \mathrm{~d} 1 \% 8 \mathrm{f}-\% \mathrm{~d} 0 \% \mathrm{ba} \% \mathrm{~d} 0 \% \mathrm{be} \% \mathrm{~d} 0 \% \mathrm{bc} \% \mathrm{~d} 0 \% \mathrm{bc} \% \mathrm{~d} 0 \% \mathrm{~b} 5 \% \mathrm{~d} 1 \% 80 \% \mathrm{~d} 1 \% 86 \% \mathrm{~d} 0 \% \mathrm{~b} 8 \% \mathrm{~d} 1 \% 8 \mathrm{f}$ (дата звернення: 27.03.2021).

9. EVO.company. URL: https://evo.company (дата звернення: 20.03.2021).

10. Український процесінговий центр : вебсайт. URL: https://upc.ua/ua/news-ua/1657.

\section{References:}

1. Moshenets O.V. (2011), «Innovative products and technologies in the banking services market», Finansovyy rynok Ukrayiny, no. 12 , pp. $7-8$.

2. Novykova K.V., Staratovych A.S. and Medvedeva E.O. (2013), Internet Marketing and E-Commerce. Study guide, Perm: Perm. hos. nats. yssled.un-t, $78 \mathrm{p}$.

3. Tardaskina T.M., Strel'chuk Ye.M. and Tereshko Yu.V. (2011) E-commerce: a textbook, Odesa: ONAZ im. O.S. Popova, 243 p.

4. Tkachuk V.O. (2013), Innovatsiyna polityka bankiv na rynku bankivs'kykh posluh. Ekonomichnyy analiz: zb. nauk. pr, vol. 14, no. 2, pp. 43-51.

5. Yudin O.M., Makarova M.V. and Lavrenyuk R.M. (2011) E-commerce systems: creation, promotion and development: a monograph, Poltava: RVV PUET, 201 p.

6. Report on e-commerce of the statistical portal Statista for 2020 (2020), Statista: web-site, available at: https://www.statista.com/ study/42335/ecommerce-report (accessed 10 March 2021).

7. Ecommerce in Europe: $€ 717$ billion in 2020 (2020), Ecommerce News europe: web-site, available at: https://ecommercenews.eu/ ecommerce-in-europe-e 717-billion-in-2020/\#: :text=Ecommerce\%20in\%20Europe\%20is\%20expected,the\%20European\%20 ecommerce\%20in\%202019 (accessed 15 March 2021).

8. E-commerce. web-site (2020), available at: https://e-ommerce.com.ua/category/\%d1\%8d $\% \mathrm{~d} 0 \% \mathrm{bb} \% \mathrm{~d} 0 \% \mathrm{~b} 5 \% \mathrm{~d} 0 \% \mathrm{ba} \% \mathrm{~d} 1 \% 82 \%$ d1\%80\%d0\%be\%d0\%bd\%d0\%bd\%d0\%b0\%d1\%8f-\%d0\%ba\%d0\%be\%d0\%bc\%d0\%bc\%d0\%b5\%d1\%80\%d1\%86\%d0\%b8\%d1\%8 f(accessed 27 March 2021).

9. EVO.company web-site (2020), available at: https://evo.company/ (accessed 20 March 2021).

10. Ukrainian processing center: web-site (2020), available at: https://upc.ua/ua/news-ua/1657.htm (accessed 29 March 2021).

Chuprina Margaryta, Lazorenko Taisiia National Technical University of Ukraine «Igor Sikorsky Kyiv Polytechnic Institute»

\section{IMPLEMENTATION OF THE INNOVATIONAL TECHNOLOGIES OF LENDING IN TERMS OF E-COMMERCE}

It is defined in the article that the development of the electronic systems creates a new virtual reality to conduct a real business in the field of electronic commerce. The implementation of the innovational technologies of crediting in the field of e-commerce is caused by the growth of the amount of bank which have started to provide an extended package of Internet services in Ukraine and around the globe. It is proved that the implementation of the innovational technologies of crediting offers possibilities to reduce the time of data processing, provide clients with a remote service and, therefore, increase the client database. There was made an analysis of the word volumes and the new trends of the e-commerce development were determined according to the terms of the world pandemic of the COVID-19, namely globalization and erasing of the borders, usage of innovational data technologies as VR/AR, voice control, Artificial Intelligence, usage of phones in the field of e-commerce. New trends and tendencies are detailed, the main problems are highlighted and also it is emphasized that the domestic market of e-commerce coexists alongside with the general world trends with specific vectors of development. There are mentioned the examples of using modern bank digital innovations in Ukraine: namely the system of wireless payment methods by Mastercard called PayPass, the launch of a global service AndroidPay and a mutual inventory of the international payment system Visa and "PrivatBank" of applicating the e-technology Visa Token Service. The expediency of distributing installments from JSC CB "PrivatBank", which promotes credit programs within card products, is substantiated on the online lending market. Particular attention ispaid to the main steps of implementing the innovational technologies by credit institutions. It is determined that the possibility of lending in e-commerce is in the interest of online stores due to having this option as a component of product distribution in the market and sales level increase. Itisalsomentioned, that such products are devoid of outdated demands of bank crediting and are competitive in the bank service market.

Key words: e-commerce, digital technologies, innovational technologies of lending.

JEL classification: M11, M21 